\title{
INEQUALITITES FOR CAUCHY MEAN VALUES
}

\section{LÁSZLÓ LOSONCZI}

Abstract. The Cauchy Mean Value Theorem for divided differences (see e.g. [16]) states the following:

Suppose that $x_{1} \leqslant \cdots \leqslant x_{n}$ and $f^{(n-1)}, g^{(n-1)}$ exist, with $g^{(n-1)} \neq 0$, on $\left[x_{1}, x_{n}\right]$. Then there is a $t \in\left[x_{1}, x_{n}\right]$ (moreover $t \in\left(x_{1}, x_{n}\right)$ if $\left.x_{1}<x_{n}\right)$ such that

$$
\frac{\left[x_{1}, \ldots, x_{n}\right]_{f}}{\left[x_{1}, \ldots, x_{n}\right]_{g}}=\frac{f^{(n-1)}(t)}{g^{(n-1)}(t)}
$$

where $\left[x_{1}, \ldots, x_{n}\right]_{f}$ denotes the divided difference of $f$ at the points $x_{1}, \ldots, x_{n}$.

If the function $\frac{f^{(n-1)}}{g^{(n-1)}}$ is invertible then

$$
t=\left(\frac{f^{(n-1)}}{g^{(n-1)}}\right)^{-1}\left(\frac{\left[x_{1}, \ldots, x_{n}\right]_{f}}{\left[x_{1}, \ldots, x_{n}\right]_{g}}\right)
$$

is a mean value of $x_{1}, \ldots, x_{n}$. It is called the Cauchy mean of the numbers $x_{1}, \ldots, x_{n}$ and will be denoted by $\mathcal{D}_{f, g}\left(x_{1}, \ldots, x_{n}\right)$.

In this survey paper we discuss the equality, homogeneity of Cauchy means and inequalities of general nature: comparison, Minkowski's inequality of (homogeneous) Stolarsky's means and also the comparison and general comparison of Cauchy means.

Mathematics subject classification (2000): 26A15.

Key words and phrases: Cauchy mean value, divided differences, inequalities.

\section{REFERENCES}

[1] W. H. AdAMS, Heat transmission, McGraw-Hill, New York, 1954.

[2] G. Allasia, C. GIORDANO AND J. PEČARIĆ, On the arithmetic and logarithmic means with applications to Stirling's formula, Atti Sem. Mat. Fiz. Univ. Modena, 47 (1999), 441-455.

[3] H. AlZER, Bestmögliche Abschätzungen für spezielle Mittelwerte, Univ. u Novom Sadu Zb. Rad. Prirod.-Mat. Fak. Ser. Mat., 23(1) (1993), 331-346.

[4] G. Aumann and O. Haupt, Einführung in die reelle Analysis, Band II, W. de Gruyter, Berlin-New York, 1979.

[5] J. BRENNER, A unified treatment and extension of some means of classical analysis I. Comparison theorems, J. Combin. Inform System Sci., 3 (1978), 175-199.

[6] J. Brenner AND B. C. CARlson, Homogeneous mean values: Weights and asymptotics, J. Math. Anal. Appl., 13 (1987), 265-280.

[7] F. BURK, By all means, Amer. Math. Monthly, 92, 1985, 50.

[8] B. C. CARlson, The logarithmic mean, Amer. Math. Monthly, 79 (1972), 615-618.

[9] P. CZINDER AND Zs. PÁles, A general Minkowski-type inequality for two variable Stolarsy means, (manuscript).

[10] Z. DARócZY AND L. LosonCZI, Über den Vergleich von Mittelwerten, Publ. Math. Debrecen, 17, (1970), 289-297. 
[11] E. L. DoDD, Some generalization of the logarithmic mean and of similar means of two variates which become indeterminate when the two variates are equal, Ann. Math. Statist., 12 (1971), 422-428.

[12] N. ElEZOVIĆ AND J. PEČARIĆ, Differential and integral $f$-means and applications to digamma function, Math. Ineq. Appl., 3 (2000), 189-196.

[13] P. FlandRIn AND P. GonÇALVÈs, Geometry of affine time-frequency distributions, Applied and Computational Harmonic Anal., 3 (1996), 10-39.

[14] E. Leach AND M. Sholander, Extended mean values, Amer. Math. Monthly, 85 (1978), 84-90.

[15] E. Leach AND M. ShOlAnder, Extended mean values II, J. Math. Anal. Appl., 92 (1983), 207-223.

[16] E. LEACH AND M. SHOLANDER, Multi-variable extended mean values, J. Math. Anal. Appl., 104 (1984), 390-407.

[17] T. P. LiN, The power mean and the logarithmic mean, Amer. Math. Monthly, 81 (1974), 879-883.

[18] L. LosONCZI, Equality of two variable weighted means: reduction to differential equations, Aequationes Math. 58 (1999), 223-241.

[19] L. LosoncZI, Ineqwualities for integral mean values, J. Math. Anal. Appl. 61 (1977), 586-606.

[20] L. LosoncZI, Equality of Cauchy means, Publ. Math. Debrecen 57 (1999), 223-241.

[21] L. LosoncZI, On the comparison of Cauchy mean values, J. of Ineq. and Appl. 7 (2002), 11-24.

[22] L. LosonCZI, Equality of two variable Cauchy means, Aequationes Math. (to appear).

[23] L. Losonczi, Homogeneous Cauchy Means, in: Functional Equations - Results and Advances (ed. by Z. Daróczy and Zs. Páles), Kluwer Acad. Publ., Dordrecht-Boston-London (2002), 209-218.

[24] L. LOSONCZI AND Zs. PÁLES, Minkowski's inequality for two variable difference means, Proc. Amer. Math. Soc. 126 (1998), 779-789.

[25] E. Neuman, The weighted logarithmic mean, J. Math. Anal. Appl., 188 (1994), 885-900.

[26] Zs. PÁLES, Inequalities for sums of powers, J. Math. Anal. Appl., 131 (1988), 265-270.

[27] Zs. PÁLES, Inequalities for differences of powers, J. Math. Anal. Appl., 131 (1988), 271-281.

[28] Zs. PÁLES, Comparison of two variable homogeneous means, General Inequalities 6. Proc. 6th Internat. Conf. Math. Res. Inst. Oberwolfach, Birkhäuser Verlag Basel, 1992, pp. 59-69.

[29] Zs. PÁLES, A unified form of the classical mean value theorems, in: Inequalities and Applications (ed. by R. P. Agarwal), World Scientific Publ., Singapore-New Jersey-London-Hong Kong, 1994, 493-500.

[30] C. E. PeARCE, J. PeČARIĆ AND J. ŠUnde, A generalization of Pólya's inequality to Stolarsky and Gini means, Math. Ineq. Appl., 1 (1998), 211-222.

[31] J. PeČARIĆ AND V. Simić, Stolarsky-Tobey mean in $n$ variables, Math. Ineq. Appl., 2 (1999), 325-341.

[32] A. O. PitTEnger, The symmetric, logarithmic, and power means, Univ. Beograd. Publ. Elektrotehn. Fak., Ser. Mat. Fiz. No. 681 (1980), 19-23.

[33] A. O. PitTEngER, The logarithmic mean in $n$ variables, Amer. Math. Monthly, 92 (1985), 99-104.

[34] G. PólYA AND G. SZEG $\phi$, Isoperimetric inequalities in mathematical physics, Princeton Univ. Press, Princeton, N. J., 1951.

[35] J. RäTZ AND D. RuSSELl, An extremal problem related to probability, Aequationes Math., 34 (1987), $316-324$.

[36] J. SÁNDOR, On certain inequalities for means, J. Math. Anal. Appl., 189 (1995), 602-606.

[37] J. SÁNDOR, On certain inequalities for means II, J. Math. Anal. Appl., 199 (1996), 629-635.

[38] J. SÁNDOR, On refinements of certain inequalities for means, Archivum Mathematicum (Brno), 31 (1995), 279-282.

[39] H. SEIFFERT, Ungleichungen für einen bestimmten Mittelwert, Nieuw Arch. Wisk., 13 (1995), 195-198.

[40] H. SEIFFERT, Ungleichungen für elementare Mittelwerte, Arch. Math. (Basel), 63 (1995), 129-131.

[41] L. SCHUMAKER, Spline functions, Wiley, New York-Toronto, 1981.

[42] J. F. STEFFENSON, Interpolation, 2nd ed., Chelsea, New York, 1950.

[43] K. B. StOlaRSKY, Generalizations of the logarithmic mean, Math. Mag., 48 (1975), 87-92.

[44] K. B. StOlARSKY, The power and generalized logarithmic means, Amer. Math. Monthly, 87 (1980), $545-548$.

[45] G. SzÉKELY, A classification of means, Ann. Univ. Sci. Budapest. Eötvös Sect. Math., 18 (1975), $129-133$.

[46] K. Tettamanti, G. SÁRKÁNy, D. KRÁliK AND R. SOMFAI, Über die Annäherung logarithmischer Funktionen durch algebraische Funktionen, Period. Polytech. Chem. Engrg., 14 (1970), 99-111.

[47] M. D. ToBeY, Two-parameter homogeneous mean value, Proc. Amer. Math. Soc., 18 (1967), 9-14. 